\title{
Effect of Soil Degradation and Remediation in Technogenic Barrens on the Uptake of Nutrients and Heavy Metals by Plants in the Kola Subarctic
}

\author{
G. N. Koptsik ${ }^{a}$ * , S. V. Koptsik ${ }^{b}$, I. E. Smirnova ${ }^{a}$, and M. A. Sinichkina ${ }^{a}$ \\ ${ }^{a}$ Soil Science Faculty, Lomonosov Moscow State University, Moscow, 119991 Russia \\ ${ }^{b}$ Faculty of Physics, Lomonosov Moscow State University, Moscow, 119991 Russia \\ *e-mail: koptsikg@mail.ru
}

Received December 29, 2020; revised March 1, 2021; accepted March 2, 2021

\begin{abstract}
To assess the state of plants and their response to changes in soil properties, the elemental composition of leaves of widespread and pollution-tolerant species Betula pubescens Ehrh. and Salix caprea L. has been studied near the nonferrous metallurgy enterprises in the Kola Peninsula. The content of nutrients and heavy metals in the leaves of undergrowth on technogenic barrens and remediation sites differing in remediation technologies has been analyzed. According to the results of leaf diagnostics, both species under barren conditions are characterized by a noticeable deficiency of K, Ca, P, and, especially, Mn and Zn. The leaves of both species accumulate $\mathrm{Ni}, \mathrm{Cu}, \mathrm{Co}, \mathrm{As}, \mathrm{Cr}, \mathrm{Fe}, \mathrm{Al}, \mathrm{Pb}, \mathrm{V}$, and $\mathrm{S}$. Willow leaves contain more $\mathrm{Cd}, \mathrm{Co}, \mathrm{Cr}$, $\mathrm{Ni}, \mathrm{Cu}, \mathrm{Al}, \mathrm{Fe}, \mathrm{As}, \mathrm{S}, \mathrm{Ca}, \mathrm{K}$ and less Mn than birch leaves. Chemophytostabilization has little effect, and the covering of contaminated soils with a constructed fertile layer leads to the enrichment of birch and willow leaves with $\mathrm{Ca}, \mathrm{K}$, and $\mathrm{P}$. Under conditions of continuing atmospheric emissions and gradual accumulation of bioavailable heavy metals in soils after the remediation, the accumulation of metals in leaves is largely determined by the distance from the pollution source, reflecting the possibility of both root and foliar uptake. The concentrations of $\mathrm{Ni}$ and $\mathrm{Cu}$ in leaves in 2018 did not decrease compared to 2011. The low, albeit varying, ratios of the contents of heavy metals in undergrowth leaves and in the soil and weak correlation of heavy metal contents in these media indicated that $B$. pubescens and $S$. caprea retain their ability to regulate their chemical composition even under extreme conditions of technogenic barrens. At the same time, supporting the protective capabilities of plants via optimizing mineral nutrition and soil acidity in combination with a reduction in atmospheric pollution is a prerequisite for efficient remediation of technogenic territories in the Far North.
\end{abstract}

Keywords: air pollution, birch, willow, leaf diagnostics, soils, nickel, copper, Albic Podzol, Entic Podzol

DOI: $10.1134 / \mathrm{S} 106422932108010 \mathrm{X}$

\section{INTRODUCTION}

Elemental composition of plants is determined by their genetic features and age and can change under the influence of edaphic and climatic factors. Traditional studies of elemental composition of plants concern the problems of mineral nutrition and biological cycle of elements $[1,26]$. With an increase in technogenic pollution, element accumulation in plants, especially in industrial regions, is greatly affected by the input of pollutants from the atmosphere. In this regard, ecological aspects of the study of chemical composition of plants, including the use of plants for bioindication and biomonitoring of atmospheric pollution [11, 12, 18, 22, 33], biogeochemical mapping $[32,34]$, and analysis of toxicity of technogenic elements [27] have come into focus in the recent decades. Special emphasis is put upon phytoremediation based on plant capacity to draw hazardous substances from the environment and to transform these substances into harmless compounds, metabolites [20, 30, 31]. Two contrasting groups of plants are separated according to their capacity to accumulate heavy metals (HMs): excluders, in which consumed metals are captured in the root system and practically do not come into the aboveground organs, and accumulators, in which metals are accumulated in the aboveground organs [19]. Excluders and accumulators are used in two alternative and widely distributed technologies of phytoremediation: phytostabilization and phytoextraction, respectively. The efficiency of phytoremediation depends on the natural capacity of plants for metal accumulation and translocation, plant tolerance towards HMs, plant capacity to form huge biomass, climatic conditions, and soil properties.

Willows (Salix spp.) are characterized by the great territorial expansion, high productivity, intense evapotranspiration, increased tolerance to HMs, and efficient consumption of nutrients; thus, they have a 
great potential in phytoextraction [31, 37-39], as well as in phytostabilization [17, 31,39]. The possibility to use aboriginal willow species for remediation purposes with a preliminary preparation of the soil substrate was demonstrated even in the case of the high level of atmospheric pollution near the Severonikel smelter in the Kola Peninsula [17]. Different willow species and clones were efficiently used for phytoextraction of $\mathrm{Cd}$ and $\mathrm{Zn}$ from contaminated soils [38]. At the same time, fast-growing willows are the source of biomass for "green" energetics. However, the capability for absorption and translocation of metals and, respectively, the suitability for phytoremediation varies significantly depending on plant species and clone and specificity of contaminated site, emphasizing the advisability of genetic selection [39].

Information on the use of birch species in phytoremediation is less available, though birch has potential for phytostabilization of contaminated soils in the boreal zone as one of the most important forest-forming species with significant ecological plasticity and adaptation to extreme environmental conditions, including technogenic impact [31].

The purpose of our work is to analyze absorption of nutrients and HMs by leaves of pubescent birch (Betula pubescens Ehrh.) and goat willow (Salix caprea L.) depending on the soil properties under the conditions of contamination and remediation of technogenic barrens near the nonferrous metallurgy enterprises in the Kola Subarctic.

\section{OBJECTS AND METHODS}

Studied objects were represented by plantations of willow and birch at sites of remediation of technogenic barrens near the Severonikel smelter (industrial site Monchegorsk at present) in the Kola Peninsula. In 2018, we studied six remediation sites with artificially created fertile layer (R), two sites of chemophytostabilization $(\mathrm{Ph})$, and three control sites of barrens $(\mathrm{B})$ and adjacent birch low forest (BLF) located $2-5 \mathrm{~km}$ from the industrial plot, which had also been studied earlier (in 2011). The location of studied sites is shown in Fig. 1; brief characteristics and coordinates of monitoring plots are given in $[7,9]$. The soil cover of barrens is represented by eroded chemically contaminated iron podzols (B-2007/8), chemozems contaminated with $\mathrm{Cu}$ and $\mathrm{Ni}$ and developed from podzols (Albic Podzols (Phytotoxic), B-2004/5), and Al-Fe-humus abrazems (Entic Podzols, B-2003/6) without upper horizons because of the intense development of erosion. For comparison, we also studied a conditionally background spruce forest (S) with birch on podzols (Folic Albic Podzols (Arenic)) $64 \mathrm{~km}$ southward from the source of pollution.

Chemophytostabilization included planting of aboriginal species of deciduous trees and shrubs (mostly willows and birches) without preliminary preparation of soil and with simultaneous sowing of perennial herbs (dominated by grasses) and application of lime flour and mineral fertilizers. The artificial fertile layer covering the contaminated soils mainly consisted of peat, sand, and wood shavings with addition of sewage sludge (R-2003, R-2006). As in the case of chemophytostabilization, seedlings of trees and shrubs were planted simultaneously with sowing of perennial grasses and application of lime and fertilizers. Tree and shrub species were represented mostly by willows ( $S$. caprea L. with admixture of $S$. phylicifolia L., $S$. cinerea L., S. glauca L., etc.) and birches (B. pubescens Ehrh.) [10]. Remediation of technogenic barrens was performed by the Monchegorsk Forestry according to recommendations of the Institute of Industrial Ecology Problems of the North (Kola Science Center, Russian Academy of Sciences) with support of the Kola Mining and Metallurgical Company in 2003-2008.

Research methods. Field study was conducted in August 2018 on 13 monitoring plots, each of which included four test subplots $(10 \times 10 \mathrm{~m})$. Additionally to geobotanical descriptions [10], the leaves were collected to characterize elemental composition of widely distributed tolerant to pollution and used in remediation species: Betula pubescens Ehrh. and Salix caprea L. Four composite samples of leaves of each species (one sample from each test plot) composed of leaves of five individual plants were taken in plantations at every remediation site. The leaves of survived wild plants were taken according to the same procedure on barrens and in birch low forest.

To determine elemental composition, not washed leaves were digested in concentrated nitric acid with addition of $30 \% \mathrm{H}_{2} \mathrm{O}_{2}$ and heating to $150^{\circ} \mathrm{C}$. Concentrations of nutrients and major and associated contaminants ( $\mathrm{S}, \mathrm{P}, \mathrm{Ca}, \mathrm{Mg}, \mathrm{K}, \mathrm{Na}, \mathrm{Al}, \mathrm{Fe}, \mathrm{Mn}, \mathrm{Ni}, \mathrm{Cu}$, $\mathrm{Co}, \mathrm{Cd}, \mathrm{Cr}, \mathrm{Pb}, \mathrm{V}, \mathrm{Zn}$, and $\mathrm{As}$ ) in extracts were determined by the method of inductively coupled plasmaoptical emission spectroscopy (ICP-OES, Agilent 5110). Overall, 62 samples of leaves were analyzed; the results were recalculated per absolutely dry weight.

The accumulation of HMs in leaves in comparison with the background level was characterized using accumulation factors. To evaluate metal absorption by plants, concentration coefficients representing the ratio of metal concentration in plant leaves to concentration of its available (extracted with $1 \mathrm{M}$ solution of $\mathrm{CH}_{3} \mathrm{COONH}_{4}$ with $\mathrm{pH} 4.8$ ) forms in soil were calculated $[8,33]$. The chemical properties of studied soils were characterized earlier [9].

The methods of descriptive statistics were applied for data treatment; we assumed the normal distribution of the properties of composite plant samples. Significance of difference between mean values was evaluated by $t$-test corresponding to the absence of overlapping of confidence intervals of mean values. The relationships between concentrations of elements in plant leaves with one another and with the soil proper- 


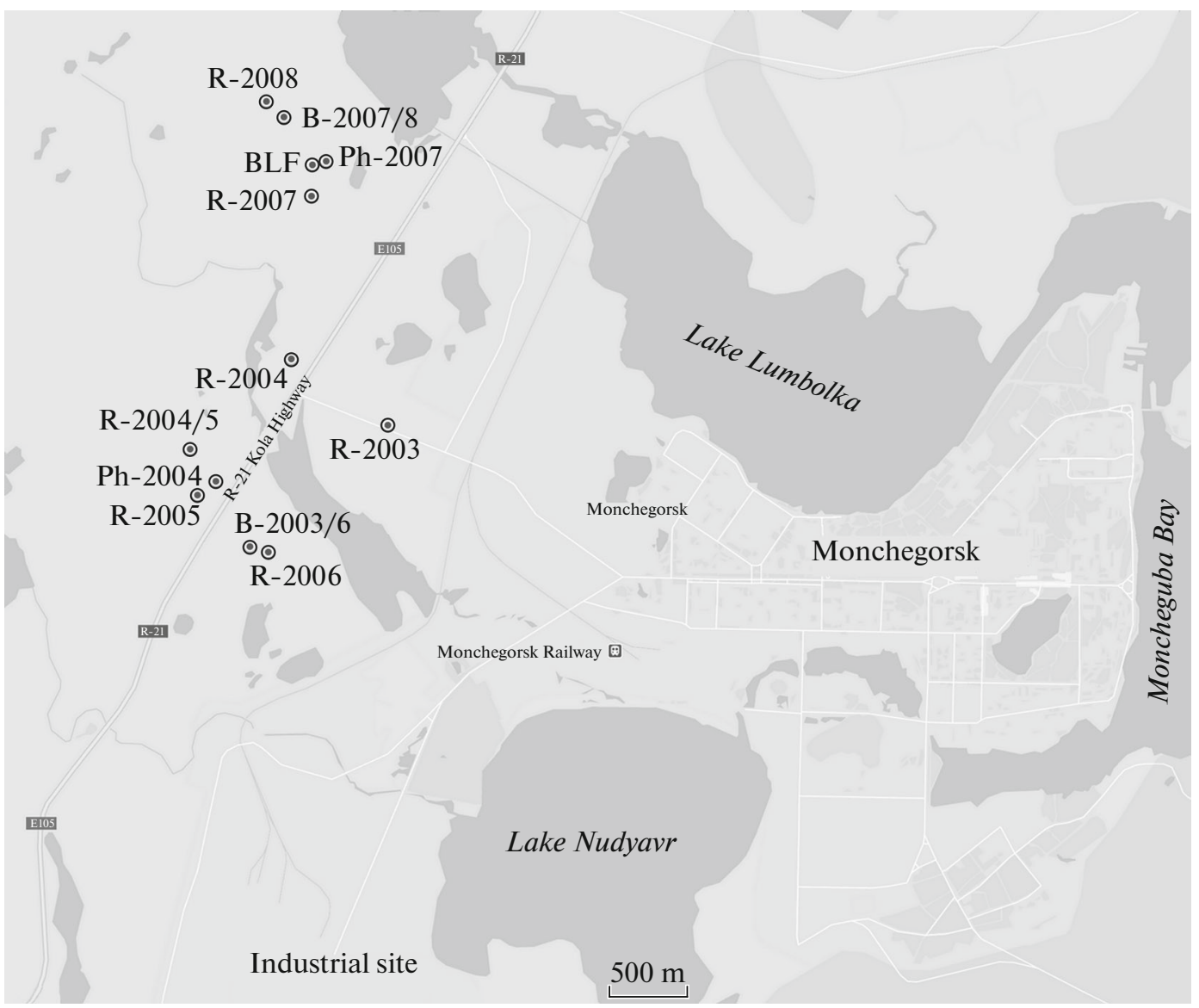

Fig. 1. Location of monitoring plots near Monchegorsk. Hereinafter: $\mathrm{B}$, barrens; $\mathrm{Ph}$, plots of chemophytostabilization; R, plots of remediation with artificially constructed fertile layer (numbers indicate the year of remediation). Barren B-2003/6 served as the control for remediation plots R-2003 and R-2006; barren B-2004/5 served as the control for remediation plots Ph-2004, R-2004, and R-2005; barren B-2007/8 served as the control for remediation plots Ph-2007, R-2007, and R-2008. BLF, birch low forest.

ties were analyzed using correlation and principal component (PC) analyses [7]. To characterize soil properties, $\mathrm{pH}_{\mathrm{H}_{2} \mathrm{O}}$, exchangeable acidity, and concentrations of available nutrients, $\mathrm{HMs}$, total $\mathrm{C}, \mathrm{N}$, and $\mathrm{S}$ were used [9]. Elemental composition of leaves, thickness of the soil layer enriched with organic matter, and distance from the pollution source were analyzed as external variables with different qualitative significance relative to the chemical properties of the soil and relative to one another. The relationship between elemental composition of the leaves and the soil properties was visualized by correlation ordination diagrams as relative positions of plant characteristics in the space of the first two PCs of soil properties.

\section{RESULTS AND DISCUSSION}

Elemental composition of leaves. Input of pollutants from the atmosphere in industrial regions affects the elemental composition of plants, and this allows using plants for the purposes of indication and monitoring of atmospheric pollution. Both birch and willow under background conditions are characterized by the low content of HMs in leaves similar to their median values calculated for eight water basins of the Barents region (Tables 1 and 2) [32]. Concentrations of the main contaminant metals- $\mathrm{Ni}, \mathrm{Cu}$, and $\mathrm{Co}-$ in the leaves of birch survived on barrens reached 250, 120, and $5 \mathrm{mg} / \mathrm{kg}$, respectively, or, 25-30 times higher than concentrations of these metals in background conditions (S-64, Fig. 2). Close concentrations and exceedances of background concentrations of these metals were typical of birch in the nearby low birch forest. In comparison with birch, willow was characterized by increased accumulation of most of the elements in leaves with close regularities of their spatial distribution. The concentrations of $\mathrm{Ni}, \mathrm{Cu}$, and $\mathrm{Co}$ in willow leaves from contaminated plots were approximately two times higher than in birch leaves and reached $450-560,210-280$, and $10-14 \mathrm{mg} / \mathrm{kg}$, respectively, exceeding the background levels by 29-36, 27-35, and 4-6 times, respectively. A relatively low (in comparison with birch leaves) exceedance of the background Co level in willow leaves on barren plots was due to an order of magnitude higher uptake of this ele- 
Table 1. Concentrations of elements $(\mathrm{mg} / \mathrm{kg})$ in the leaves of birch from birch low forest (BLF), barrens (B), chemophytostabilization plots $(\mathrm{Ph})$, and remediation plots with creation of a new fertile layer (R) near Monchegorsk in 2018 (above the line, mean; under the line, half-width of $95 \%$ confidence interval for the mean; $n=4$ composite samples)

\begin{tabular}{|c|c|c|c|c|c|c|c|c|c|c|c|c|c|c|c|c|c|c|}
\hline Plot & $\mathrm{S}$ & $\mathrm{P}$ & $\mathrm{Ca}$ & $\mathrm{Mg}$ & K & $\mathrm{Na}$ & $\mathrm{Al}$ & $\mathrm{Fe}$ & $\mathrm{Mn}$ & $\mathrm{Ni}$ & $\mathrm{Cu}$ & Co & As & $\mathrm{Cd}$ & $\mathrm{Cr}$ & $\mathrm{Pb}$ & V & $\mathrm{Zn}$ \\
\hline \multirow{2}{*}{ BLF } & 1490 & $\underline{800}$ & 4090 & 130 & $\underline{4920}$ & $\underline{73}$ & 137 & $\underline{236}$ & 427 & 241 & $\underline{116}$ & 4.7 & $\underline{1.1}$ & $\underline{0.079}$ & $\underline{0.71}$ & $\underline{1.2}$ & $\underline{5.6}$ & 15 \\
\hline & 340 & $\overline{300}$ & $\overline{2410}$ & $\overline{1240}$ & $\overline{2240}$ & $\overline{29}$ & $\overline{224}$ & $\overline{434}$ & $\overline{266}$ & $\overline{231}$ & $\overline{133}$ & $\overline{5.2}$ & $\overline{1.3}$ & $\overline{0.087}$ & $\overline{1.4}$ & $\overline{1.7}$ & $\overline{9.6}$ & $\overline{11}$ \\
\hline \multirow{2}{*}{ B-2007/8 } & 1380 & 930 & 5600 & 2450 & 5510 & 101 & 126 & 143 & 208 & 247 & 123 & 5.3 & 1.2 & 0.042 & 0.49 & 1.07 & 2.9 & 29 \\
\hline & 230 & $\overline{400}$ & $\overline{1300}$ & 270 & $\overline{1330}$ & 26 & $\overline{20}$ & 53 & 75 & 26 & $\overline{18}$ & $\overline{0.61}$ & $\overline{0.16}$ & $\overline{0.022}$ & $\overline{0.32}$ & $\overline{0.19}$ & $\overline{0.93}$ & $\overline{15}$ \\
\hline \multirow{2}{*}{ Ph-2007 } & $\underline{1920}$ & 930 & 7810 & $\underline{3180}$ & $\underline{6910}$ & 52 & 221 & 187 & $\underline{406}$ & 253 & $\underline{137}$ & $\underline{6.2}$ & $\underline{0.88}$ & 0.13 & $\underline{0.59}$ & 1.5 & $\underline{3.5}$ & 57 \\
\hline & $\overline{410}$ & 260 & $\overline{970}$ & 640 & $\overline{1140}$ & $\overline{44}$ & $\overline{143}$ & $\overline{168}$ & 86 & $\overline{72}$ & 30 & $\overline{1.9}$ & $\overline{0.94}$ & $\overline{0.081}$ & $\overline{0.53}$ & $\overline{0.24}$ & 1.5 & 40 \\
\hline R-2003 & 1250 & 760 & 7160 & 1670 & 4490 & 63 & 77 & 93 & 63 & 213 & 121 & 4.1 & $<\mathrm{DL}$ & $<\mathrm{DL}$ & 0.23 & $<\mathrm{DL}$ & 2.2 & 120 \\
\hline \multirow{2}{*}{ R-2006 } & $\underline{3090}$ & 2420 & 10900 & $\underline{1810}$ & $\underline{9010}$ & 176 & $\underline{118}$ & $\underline{191}$ & 145 & $\underline{366}$ & 172 & 7.6 & 1.3 & $\underline{0.091}$ & $\underline{0.70}$ & 1.4 & 5.5 & $\underline{105}$ \\
\hline & $\overline{910}$ & $\overline{1400}$ & $\overline{3950}$ & $\overline{270}$ & $\overline{4930}$ & $\overline{37}$ & $\overline{47}$ & $\overline{70}$ & $\overline{44}$ & $\overline{184}$ & $\overline{106}$ & $\overline{5.2}$ & $\overline{0.36}$ & $\overline{0.010}$ & $\overline{0.29}$ & $\overline{0.005}$ & $\overline{0.48}$ & $\overline{56}$ \\
\hline \multirow{2}{*}{ R-2007 } & 2210 & $\underline{3880}$ & 14000 & $\underline{2970}$ & 8640 & $\underline{165}$ & $\underline{93}$ & 164 & 177 & 207 & 106 & 4.2 & $\underline{1.1}$ & 0.074 & $\underline{0.65}$ & $\underline{0.83}$ & 3.3 & 76 \\
\hline & $\overline{440}$ & $\overline{1000}$ & $\overline{4130}$ & $\overline{410}$ & $\overline{1560}$ & $\overline{10}$ & $\overline{25}$ & $\overline{76}$ & $\overline{55}$ & $\overline{63}$ & $\overline{17}$ & $\overline{1.4}$ & $\overline{1.2}$ & $\overline{0.022}$ & $\overline{0.31}$ & $\overline{0.88}$ & $\overline{1.1}$ & $\overline{28}$ \\
\hline \multirow{2}{*}{ R-2008 } & $\underline{2160}$ & $\underline{3190}$ & 11200 & $\underline{2890}$ & $\underline{9370}$ & 272 & $\underline{145}$ & $\underline{209}$ & 719 & 284 & $\underline{141}$ & $\underline{8.8}$ & $\underline{1.0}$ & $\underline{0.28}$ & $\underline{0.94}$ & 1.0 & $\underline{3.2}$ & 84 \\
\hline & $\overline{800}$ & $\overline{620}$ & $\overline{5620}$ & 540 & 980 & $\overline{111}$ & $\overline{20}$ & $\overline{133}$ & 143 & $\overline{105}$ & 55 & 2.7 & 1.1 & $\overline{0.12}$ & 0.58 & $\overline{0.33}$ & $\overline{1.1}$ & $\overline{11}$ \\
\hline \multirow{2}{*}{ S-64* } & $\underline{870}$ & $\underline{1340}$ & $\underline{7170}$ & $\underline{2490}$ & $\underline{5940}$ & $\underline{73}$ & $\underline{51}$ & $\underline{40}$ & $\underline{1260}$ & $\underline{8.3}$ & $\underline{4.3}$ & $\underline{0.21}$ & \multirow{2}{*}{$<\mathrm{DL}$} & $\underline{0.13}$ & $\underline{0.15}$ & \multirow{2}{*}{$<\mathrm{DL}$} & \multirow{2}{*}{$<\mathrm{DL}$} & $\underline{85}$ \\
\hline & $\overline{240}$ & $\overline{300}$ & $\overline{840}$ & $\overline{470}$ & $\overline{2050}$ & $\overline{60}$ & $\overline{57}$ & $\overline{20}$ & $\overline{510}$ & $\overline{2.0}$ & $\overline{1.0}$ & $\overline{0.09}$ & & $\overline{0.04}$ & $\overline{0.11}$ & & & $\overline{34}$ \\
\hline $\begin{array}{l}\text { Barents } \\
\text { region** }\end{array}$ & 1750 & 2300 & 11000 & 3940 & 10300 & $<20$ & 27 & 82 & 1470 & 3.9 & 5.7 & 0.36 & 0.03 & 0.25 & $<0.20$ & 0.31 & 0.10 & 205 \\
\hline
\end{tabular}

* Conventionally background spruce forest ( $64 \mathrm{~km}$ from the source of pollution).

** Medians for eight water basins of the Barents region [32].

Table 2. Concentrations of elements $(\mathrm{mg} / \mathrm{kg})$ in willow leaves on barrens $(\mathrm{B})$, chemophytostabilization plots $(\mathrm{Ph})$, and remediation plots with fertile layer (R) near Monchegorsk in 2018 (above the line, mean; under the line, half-width of 95\% confidence interval for the mean, $n=4$ composite samples)

\begin{tabular}{|c|c|c|c|c|c|c|c|c|c|c|c|c|c|c|c|c|c|c|}
\hline Plot & S & $\mathrm{P}$ & $\mathrm{Ca}$ & $\mathrm{Mg}$ & K & $\mathrm{Na}$ & $\mathrm{Al}$ & $\mathrm{Fe}$ & $\mathrm{Mn}$ & $\mathrm{Ni}$ & $\mathrm{Cu}$ & Co & As & $\mathrm{Cd}$ & $\mathrm{Cr}$ & $\mathrm{Pb}$ & $\mathrm{V}$ & $\mathrm{Zn}$ \\
\hline B-2004/5 & 1780 & 640 & 9760 & 3410 & 7400 & 49 & 214 & 189 & 406 & 448 & 213 & 9.8 & 0.98 & 0.14 & 0.41 & 1.09 & 3.5 & 12 \\
\hline \multirow[t]{2}{*}{ B-2007/8 } & 1730 & 900 & 15900 & 2670 & 8860 & 145 & 374 & 410 & 100 & 557 & 279 & 14.1 & 1.8 & 0.25 & 1.28 & 1.81 & 5.2 & 18 \\
\hline & $\overline{100}$ & $\overline{225}$ & $\overline{5420}$ & $\overline{890}$ & $\overline{2050}$ & $\overline{148}$ & $\overline{99}$ & $\overline{171}$ & $\overline{137}$ & $\overline{146}$ & $\overline{93}$ & $\overline{2.7}$ & $\overline{0.33}$ & $\overline{0.16}$ & $\overline{1.21}$ & $\overline{0.34}$ & $\overline{0.60}$ & $\overline{18}$ \\
\hline \multirow[t]{2}{*}{ Ph-2004 } & $\underline{2380}$ & $\underline{1200}$ & 16600 & $\underline{3250}$ & 5360 & $\underline{154}$ & 272 & 231 & $\underline{307}$ & 574 & $\underline{193}$ & $\underline{15.0}$ & 1.5 & $\underline{0.34}$ & 0.56 & 0.97 & $\underline{2.8}$ & $\underline{57}$ \\
\hline & $\overline{1270}$ & $\overline{800}$ & $\overline{9800}$ & $\overline{1350}$ & $\overline{1570}$ & $\overline{80}$ & $\overline{231}$ & $\overline{236}$ & $\overline{352}$ & $\overline{155}$ & $\overline{78}$ & $\overline{4.3}$ & $\overline{0.5}$ & $\overline{0.26}$ & $\overline{0.81}$ & $\overline{1.07}$ & $\overline{2.1}$ & $\overline{67}$ \\
\hline \multirow[t]{2}{*}{ R-2003 } & 2450 & 1050 & 24800 & 2050 & 12500 & 154 & 402 & 361 & 56 & 802 & 410 & 17.5 & 1.8 & 1.82 & 1.16 & 1.88 & 5.4 & 141 \\
\hline & $\overline{530}$ & $\overline{200}$ & $\overline{5600}$ & $\overline{650}$ & $\overline{5110}$ & $\overline{16}$ & $\overline{301}$ & $\overline{267}$ & $\overline{24}$ & $\overline{475}$ & $\overline{199}$ & 11.0 & $\overline{0.88}$ & $\overline{2.05}$ & $\overline{0.89}$ & $\overline{0.89}$ & $\overline{3.4}$ & 149 \\
\hline \multirow[t]{2}{*}{ R-2004 } & 2190 & 1160 & 17600 & 4700 & 9210 & 98 & 177 & 255 & 234 & 641 & 216 & 23.0 & 1.3 & 1.07 & 0.69 & 1.03 & 3.8 & 66 \\
\hline & $\overline{300}$ & $\overline{300}$ & $\overline{3930}$ & $\overline{1470}$ & $\overline{2470}$ & $\overline{58}$ & $\overline{85}$ & $\overline{108}$ & $\overline{257}$ & $\overline{144}$ & $\overline{105}$ & $\overline{6.5}$ & $\overline{0.52}$ & $\overline{0.77}$ & $\overline{0.37}$ & $\overline{0.34}$ & $\overline{1.5}$ & $\overline{29}$ \\
\hline \multirow[t]{2}{*}{ R-2005 } & 2610 & 1950 & 21300 & 2000 & 11300 & 155 & 122 & 176 & $\underline{33}$ & 374 & 105 & 9.4 & 0.99 & 1.26 & 0.50 & 0.66 & 2.4 & $\underline{57}$ \\
\hline & $\overline{180}$ & $\overline{930}$ & $\overline{3470}$ & $\overline{850}$ & $\overline{2070}$ & $\overline{27}$ & $\overline{39}$ & $\overline{92}$ & $\overline{16}$ & $\overline{104}$ & $\overline{38}$ & $\overline{2.9}$ & $\overline{1.1}$ & $\overline{0.46}$ & $\overline{0.17}$ & $\overline{0.76}$ & $\overline{1.2}$ & $\overline{46}$ \\
\hline R-2006 & 4750 & 2640 & 19960 & 1480 & 8420 & 500 & 188 & 277 & 20 & 747 & 304 & 17.0 & 1.95 & 1.74 & 4.52 & 2.24 & 8.1 & 127 \\
\hline \multirow[t]{2}{*}{ R-2008 } & 2690 & 3230 & 16600 & 2140 & 10300 & 237 & 245 & 360 & 183 & 435 & 178 & 13.5 & 1.6 & 3.21 & 1.06 & 1.04 & 3.7 & 60 \\
\hline & $\overline{720}$ & $\overline{670}$ & $\overline{4770}$ & $\overline{380}$ & $\overline{1370}$ & $\overline{97}$ & $\overline{51}$ & $\overline{229}$ & $\overline{110}$ & $\overline{100}$ & $\overline{43}$ & $\overline{1.3}$ & $\overline{1.0}$ & $\overline{1.30}$ & $\overline{0.47}$ & $\overline{0.39}$ & $\overline{1.2}$ & $\overline{15}$ \\
\hline \multirow[t]{2}{*}{ S-64* } & 1410 & 1180 & 18400 & 3130 & 12350 & $\underline{73}$ & 110 & 120 & 156 & 15 & 7.9 & 2.3 & $<\mathrm{DL}$ & $\underline{0.33}$ & 0.31 & $<\mathrm{DL}$ & 4.4 & $\underline{55}$ \\
\hline & $\overline{330}$ & $\overline{350}$ & $\overline{6970}$ & $\overline{1560}$ & $\overline{6880}$ & $\overline{83}$ & $\overline{45}$ & $\overline{73}$ & $\overline{269}$ & $\overline{9.8}$ & $\overline{5.6}$ & $\overline{1.5}$ & & $\overline{0.34}$ & $\overline{0.49}$ & & $\overline{8.0}$ & $\overline{70}$ \\
\hline $\begin{array}{l}\text { Barents } \\
\text { region ** }\end{array}$ & 2930 & 3600 & 11000 & 3010 & 16500 & 23 & 25 & 79 & 310 & 9.0 & 7.73 & 1.76 & 0.02 & 0.68 & $<0.2$ & 0.21 & 0.05 & 125 \\
\hline
\end{tabular}

* Conventionally background spruce forest ( $64 \mathrm{~km}$ from the source of pollution).

** Medians for eight water basins of the Barents region [32].

EURASIAN SOIL SCIENCE Vol.54 No. 82021 


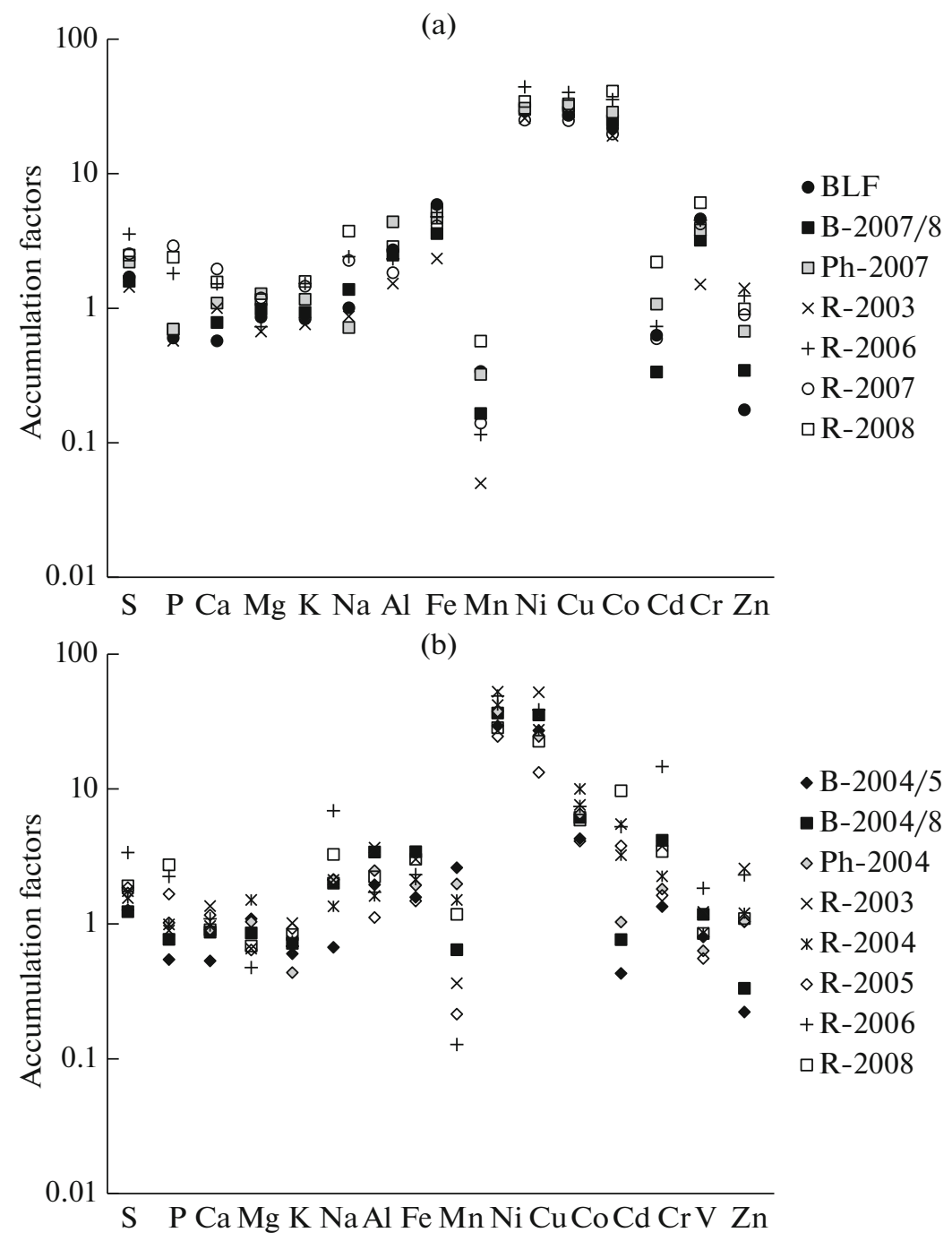

Fig. 2. Accumulation factors of elements in the leaves of (a) birch and (b) willow relative to background concentrations of these elements (logarithmic scale).

ment under background conditions. Concentrations of $\mathrm{Cd}$ in willow leaves were 2-6 times greater than those in birch leaves. Leaves of both species on contaminated plots had 2-4 times higher concentrations of $\mathrm{Cr}, \mathrm{Fe}$, and $\mathrm{Al}$ in comparison with the background levels; they also accumulated $\mathrm{S}, \mathrm{Pb}, \mathrm{V}$, and As. High concentrations of $\mathrm{Al}$ and $\mathrm{Fe}$ can indicate the input of mineral dust as a result of erosion on wide open spaces of barrens additionally to the technogenic pollution. Both birch and willow suffer from significant shortages of $\mathrm{P}, \mathrm{K}, \mathrm{Ca}$, and, especially, $\mathrm{Mn}$ and $\mathrm{Zn}$. Willow leaves under background conditions and on barrens were 1.5-3 times richer in $\mathrm{K}$ and $\mathrm{Ca}$ and 1.5 times poorer in $\mathrm{Zn}$ and 2-8 times poorer in $\mathrm{Mn}$ than birch leaves. The observed changes in metal concentrations on polluted barrens suggest the disturbance of the balance of nutrients and contaminating metals in plants, which may be indicative of the disbalance of major metabolic processes in extremely unfavorable habitats of technogenic barrens. The deficiency of $\mathrm{Mn}$ and $\mathrm{Zn}$ can be caused by competition with the main metal contaminants: $\mathrm{Cu}, \mathrm{Ni}$, and $\mathrm{Fe}$. The maximum number of antagonistic reactions is usually observed for $\mathrm{Fe}$, $\mathrm{Mn}, \mathrm{Cu}$, and $\mathrm{Zn}$ that participate in many physiological processes in plants [4]. Optimal $\mathrm{Fe} / \mathrm{Mn}$ ratio corresponding to that under background conditions is important for normal photosynthesis and plant development. High exceedance of this ratio near the source of pollution attests to disbalance of metals, sharp deficiency of Mn, and stress state of plants [13] as the response to injuring influence of contamination up to a decrease in productivity and death of plants.

Leaves of birch and willow planted in the course of chemophytostabilization in 2004 and 2007 (Ph-2004 and $\mathrm{Ph}-2007)$ were slightly enriched with $\mathrm{Ca}$ in 2018 , but little differed in concentrations of most other elements from the leaves of these plants survived on bar- 
rens (B-2004/5 and B-2007/8) and in the birch low forest. The deficiency of $\mathrm{P}, \mathrm{Zn}$, and, especially, $\mathrm{Mn}$ was preserved in birch leaves in comparison with background values. The absolute $\mathrm{K}$ deficiency in willow was enhanced by $\mathrm{K}$ deficiency relative to $\mathrm{Ca}$, as the $\mathrm{K} / \mathrm{Ca}$ ratio ( 0.3$)$ was below the critical value (0.5 [24]). Concentrations of $\mathrm{Ni}$ and $\mathrm{Cu}$ in the leaves of birch and willow at contaminated plots were $31-32$ and 25-38 times higher than those at the background plot; the concentration of Co, 29 and 7 times higher; and concentrations of $\mathrm{Al}, \mathrm{Fe}$, and $\mathrm{Cr}, 4-5$ and 2 times higher, respectively.

The results of leaf analysis attest to the improvement of plant nutrition as a result of remediation with artificially formed fertile layer. Birch leaves on these plots became significantly enriched in $\mathrm{Ca}, \mathrm{K}, \mathrm{P}$, and $\mathrm{Zn}$ in comparison with birch leaves on most of barren plots. Willow leaves were enriched in these nutrients only on the reclaimed plots in remote positions relative to the source of contamination. However, the enrichment with $\mathrm{Ca}$ resulted in misbalance of nutrients and possible relative deficiency of $\mathrm{K}$, especially in willow leaves (K/Ca 0.4-0.5). The deficiency of $\mathrm{Mn}$ remained in all plantations of birch and most plantations of willow. Extremely low Mn content and high $\mathrm{Fe} / \mathrm{Mn}$ ratio in birch and willow leaves were observed on remediation plots nearest to the source of contamination (R-2006 and R-2003).

Concentrations of $\mathrm{Ni}$ and $\mathrm{Cu}$ in the leaves of birch and willow on remediation plots with artificial fertile layer did not differ significantly from their concentrations on contaminated barren plots and exceeded the background levels by $20-40$ times (up to $40-50$ times in plantations on the plots nearest to the source of pollution (R-2003, R-2006)). Concentrations of Co were 20-40 times higher than the background values in birch leaves and 4-10 times higher in willow leaves. Concentrations of $\mathrm{Cd}$ in willow leaves were 16 times higher than those in birch leaves and 5 times higher than the background level. Concentrations of $\mathrm{Cr}$ in leaves of both species were 1.5-15 times higher than the background levels; concentrations of $\mathrm{Fe}$ and $\mathrm{Al}$, 1.5-5 times higher; and concentrations of S, 1.53.5 times higher. Maximum concentrations of these elements in birch and willow leaves were observed on remediation plots nearest to the source of pollution. Increased concentrations were also typical of $\mathrm{Pb}, \mathrm{V}$, and As. On one hand, this distribution reflects specificity of metal absorption by different plant species; on the other hand, it attests to increased availability of metals in the soil as a result of gradual metal accumulation after remediation [9]. Surface deposition as a way of metal input onto birch and willow leaves may also take place along with metal uptake by roots. Despite the increased accumulation of HMs in birch and willow leaves in plantations nearest to the source of pollution, a satisfactory state of these plantations [10] in contrast to the adjacent area of barrens (B-2003/6), where plants had died out, should be emphasized.
According to the results of correlation analysis, concentrations of $\mathrm{Ni}$ and $\mathrm{Cu}$ in birch leaves on barren plots and remediation plots are directly correlated with concentrations of $\mathrm{Co}, \mathrm{Cr}, \mathrm{Cd}, \mathrm{V}, \mathrm{Pb}, \mathrm{Fe}$, and $\mathrm{As}(r=$ $0.58-0.96, \alpha<0.001)$, which reflects the common source of these elements, and are inversely correlated with the distance from the industrial site $(r=-0.41-$ $0.43, \alpha<0.05$ ). For willow leaves, the correlation of $\mathrm{Ni}$ and $\mathrm{Cu}$ concentrations with other HMs and with As is weaker $(r=0.45-0.88, \alpha<0.01)$, and the correlation with the distance from the industrial site is insignificant.

Temporal dynamics. The decrease in atmospheric emissions of pollutants is usually reflected in the decreased concentrations of these pollutants in assimilatory plant organs $[6,12,22]$. In the studied region, such a decrease was noted of $\mathrm{Ni}$ and $\mathrm{Cu}$ concentrations in needles of spruce [8], pine, and leaves of some dwarf shrubs [12], which the authors connected with the decrease in the amount of metal-containing dust deposited on the surface of the leaves as a result of the reduction of emissions. After intense decrease in atmospheric emissions from the Sredneural'skii Copper Smelter, the decrease in surface contamination of herbaceous plants in meadow ecosystems was noted, which was confirmed by similarity of metal concentrations in not treated and washed plants [14]. Despite the decrease of emissions in 1990-2000 and small fluctuations later on, by the end of growing season of 2018, birch leaves at all monitoring sites around Monchegorsk accumulated greater amounts of the main contaminating metals (Ni and $\mathrm{Cu}$ ) than in the same season in 2011 [7] (Fig. 3), though the difference was not always statistically significant. The changes in Co accumulation were insignificant. The obtained values were within the middle and lower parts of a wide range of $\mathrm{Ni}(100-380 \mathrm{mg} / \mathrm{kg})$ and $\mathrm{Cu}(40-840 \mathrm{mg} / \mathrm{kg})$ concentrations in birch leaves within $2-5 \mathrm{~km}$ from the smelter recorded in the period of intense emissions in 1991-1994 [25]. Current concentration of $\mathrm{Ni}$ in birch leaves exceeds the threshold value $160 \mathrm{mg} / \mathrm{kg}$, specified for mortality, as well as for population renewal [2]. Willow leaves accumulated more $\mathrm{Ni}, \mathrm{Cu}$, and $\mathrm{Co}$ during the growing season of 2018 in comparison with the growing season of 2011 in three out of five remediation plots. Maximum statistically significant exceedances were typical of the plot nearest to the source of pollution (R-2003). A tendency for Al accumulation and loss of $\mathrm{Fe}$ and $\mathrm{K}$ in willow leaves was noted. Birch leaves were depleted of Mn. On the contrary, a tendency for the enrichment of birch and willow leaves with $\mathrm{Ca}$ on remediation plots was observed. Note the depletion of $\mathrm{S}$ in the leaves at all the plots in 2018 in in comparison with 2011; this depletion was especially pronounced in willow leaves. It should be noted that birch and willow are characterized by less evident response to the emission decrease in comparison with the other plants [6].

Taking into consideration the capability of plants to control uptake of pollutants by the roots, the observed dynamics could be partly explained by the continuing 


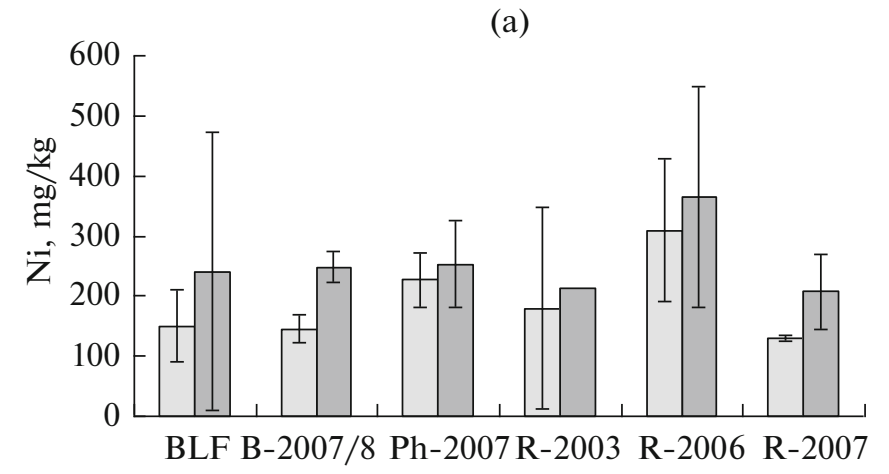

(b)

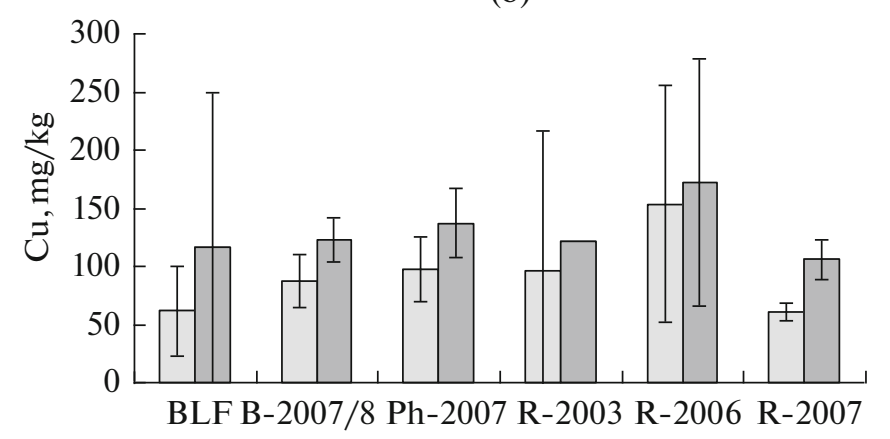

(c)

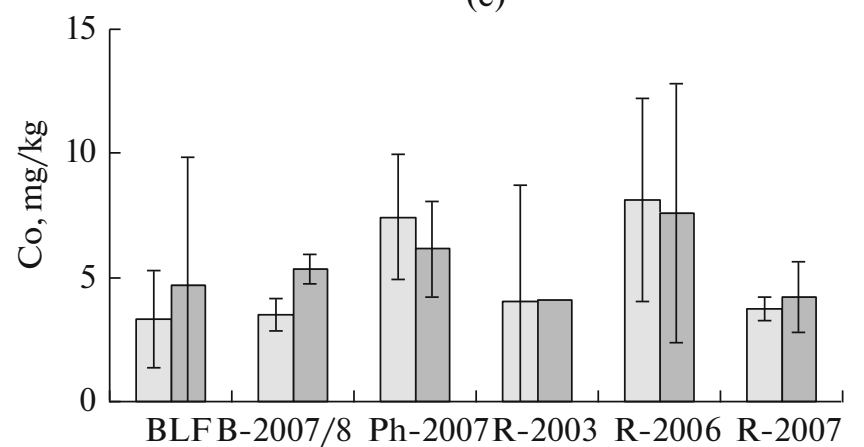

(d)

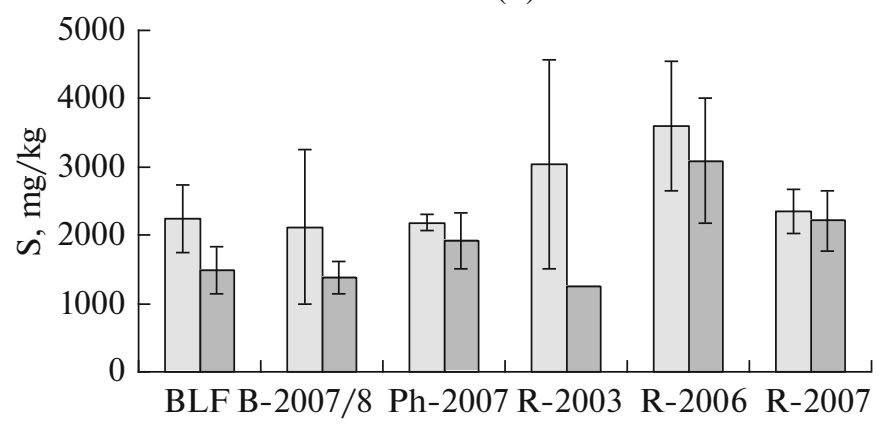

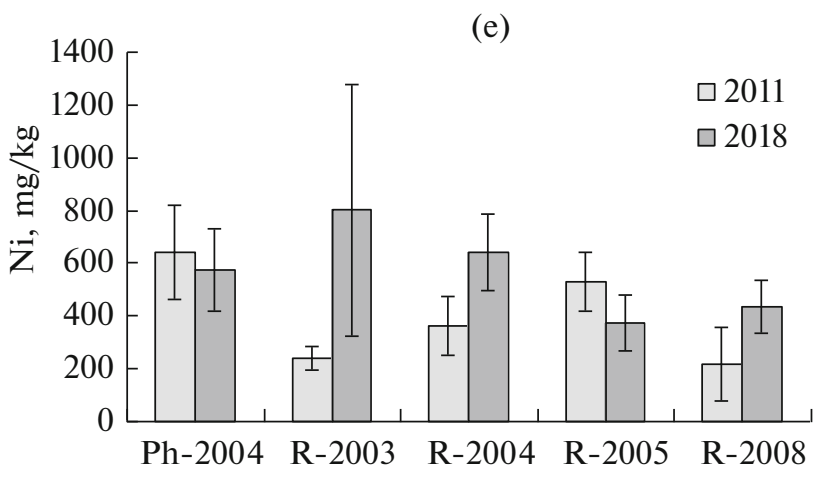

(f)

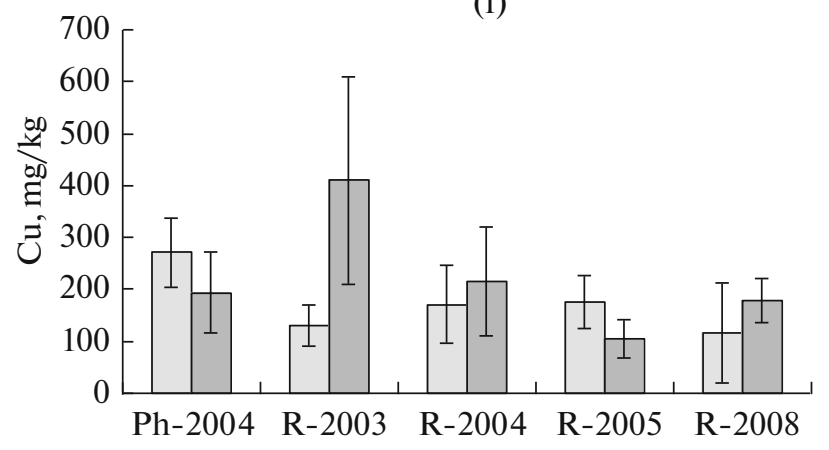

(g)

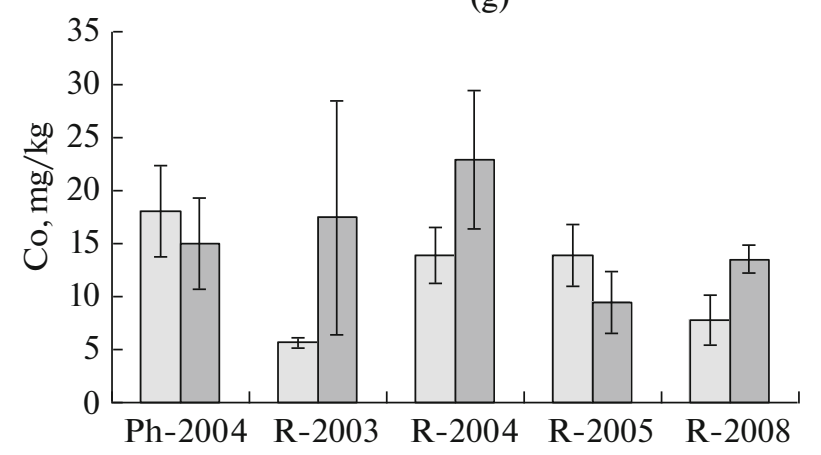

(h)

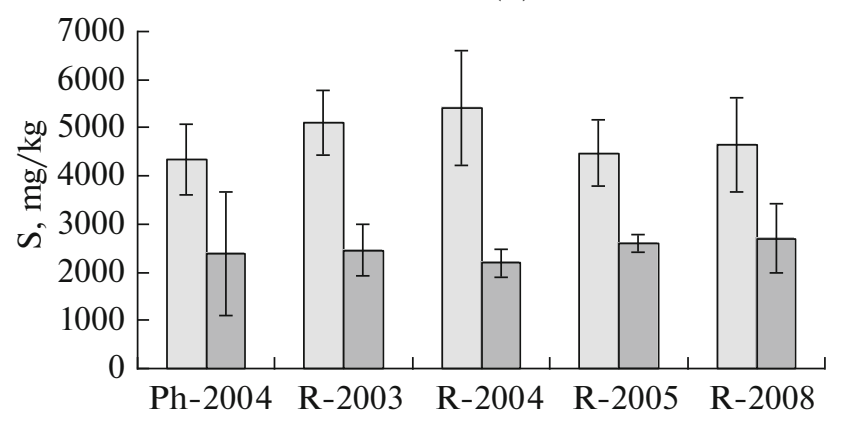

Fig. 3. Concentrations of $\mathrm{Ni}, \mathrm{Cu}, \mathrm{Co}$, and $\mathrm{S}$ in leaves of (a, b, c, d) birch and (e, f, g, h) willow on barrens and remediation plots in 2011 and 2018. Mean values and their $95 \%$ confidence intervals are given.

surface deposition of metals on leaf blades. A significant contribution to the input of metals could be due to secondary pollution of the territory because of dusting of ash-heaps and open forestless areas of technogenic barrens. The quantity of metal particles settled down and retained on the surface of leaf blades depends on the nature and size of the particles, weather conditions, leaf size and orientation, and leaf moisture and surface properties; it is subjected to considerable variations from year to year [18, 25]. Heavy 
metals can penetrate into plant tissues through the cuticle defects and stomata. Despite some toxic effects on different metabolic and physiological processes in plants, the degree of toxicity is generally lower in the case of leaf absorption in comparison with root absorption [3, 35]. However, deposition on leaf surface may negatively affect the processes of photosynthesis, respiration, and leaf feeding. Thus, the accumulation of heavy metals in leaves not only retards plant growth but also causes the return of metals to the soil after leaf fall.

Uptake of metals from soil to plant, especially to aboveground plant organs, is an important physiological process determining the efficiency of plant use for remediation of contaminated soils. Metal consumption by plants is quantitatively characterized by a number of terminologically different coefficients that generally reflect the ratio between metal concentrations in the plant and in the soil. These are the classical coefficient of biological absorption [15], concentration factor CF [33], bioconcentration factor [40], soil-plant uptake factor [21], enrichment factor [28], soil-toplant transfer factor [23], or translocation factor [36]. Evaluation of metal absorption by plants with the help of concentration factor CF involves some problems related to the possibility of using data on the total metal content in the soil or on the content of its available forms, on one hand, and to the appropriate choice of the thickness of the root layer for comparison [33]. Calculation of CF relative to the total metal content in the soil is not exactly correct, because it underestimates the real metal uptake from the soil, as a significant part of the total metal content is in the form unavailable for plants. Following previous works [8] and literature sources $[33,36]$, we calculated $C F$ relative to the concentration of bioavailable metal compounds in the soil, because this provided more adequate evaluation of metal income to the aboveground part of plant. Most roots in boreal forests are usually accumulated in the upper organic horizon enriched with nutrients. Similar conditions are formed as a result of remediation of technogenic barrens, so we took for comparison upper soil layer enriched with organic matter and nutrients. It should be noted that surface deposition of metals under the conditions of atmospheric pollution overestimates the calculated values of $\mathrm{CF}$, but the decrease in emissions levels the differences.

Concentrations of most vital elements in leaves of birch and willow significantly exceed concentrations of their bioavailable compounds in the soil, which attests to the capacity of plants for active uptake and transportation of these elements from roots to leaves (Fig. 4). Maximum CF values are typical for major nutrients, such as $\mathrm{Ca}, \mathrm{Mg}, \mathrm{K}$, and $\mathrm{P}$; high $\mathrm{CF}$ values are typical for $\mathrm{Mn}, \mathrm{Zn}$, and $\mathrm{S}$ that play an important role in metabolic processes. Especially high accumulation of $\mathrm{Mn}$ is typical of birch. Root uptake is the main source of the supply of nutrients to plants even under the conditions of increased atmospheric pollution [29].
On the contrary, judging from low CF values, both plant species restrain the input of potentially toxic $\mathrm{Cu}$, $\mathrm{Pb}, \mathrm{Al}$, and excessive $\mathrm{Fe}$; birch also limits the input of $\mathrm{Cd}$ to the assimilating organs. Toxic effects of HMs are based on binding of functional groups in biomolecules, substitution of vitally important metals from metal-containing complexes, and generation of active forms of oxygen. Despite great biological importance, $\mathrm{Cu}$ is required by plants in small quantities, and its concentration of $20-100 \mathrm{mg} / \mathrm{kg}$ is considered toxic [4]. This limit was significantly exceeded in the leaves of both species, apparently due to surface deposition. Despite the domination of copper in atmospheric emissions and fivefold domination of its available compounds in soils, birch leaves contained, on average, 1.7, and willow leaves, 2.3 times smaller amounts of $\mathrm{Cu}$ than $\mathrm{Ni}$, and this suggests the activation of barrier functions of plants to the toxicant.

Protection mechanisms of plants to HM contamination at the cellular and molecular levels include preventing of metal penetration to cell, as well as intracellular mechanisms. Penetration of metals into plant cells is limited or prevented with the help of production of metal-chelating ligands, fixation of metals in mycorrhiza, immobilization of metals in cell wall, inhibition of transport through plasmalemma, and active removal from the cells. Intracellular mechanisms of plant tolerance towards HM pollution include detoxication of HMs via formation of physiologically inactive complexes and HM removal into vacuoles, reparation of damaged cell structures, and maintenance of metabolism. Particular mechanisms of tolerance also act at plant tissue and organism levels $[3,4,16,18]$. For example, a number of mechanisms prevent the excessive absorption of HMs by roots from the soil and their transport into aboveground organs. Accumulation of $\mathrm{Cu}, \mathrm{Pb}, \mathrm{Ni}, \mathrm{Cr}$, and As in willow roots was observed earlier in greenhouse and field experiments [31, 37].

Unlike $\mathrm{Cu}$, Ni does not fall within the range of elements with limited root uptake in the studied barrens, as seen from its $\mathrm{CF}$ values. This fact suggests not only the direct input of $\mathrm{Ni}$ on the leaves with dust particles but also a lower toxicity of this element. The accumulation of Co in the leaves of fast-growing birch and willow under extremely severe conditions can be caused by participation of this element in nitrogen fixation and acceleration of plant growth and development [33]. Cadmium is not ranked among vitally important microelements; it is potentially toxic, but, owing to its high mobility, Cd can be easily consumed by plants [4]. Particularly, willow has a strong capacity for Cd accumulation in the leaves, which was demonstrated earlier during the wide-scale study of nine watersheds in North Europe [33], the impact zone of Severonikel smelter [6], and remediation experiments [37]. In general, the CF value of every element varies strongly in space and depends on specific characteristics of a given element and plant. 
(a)

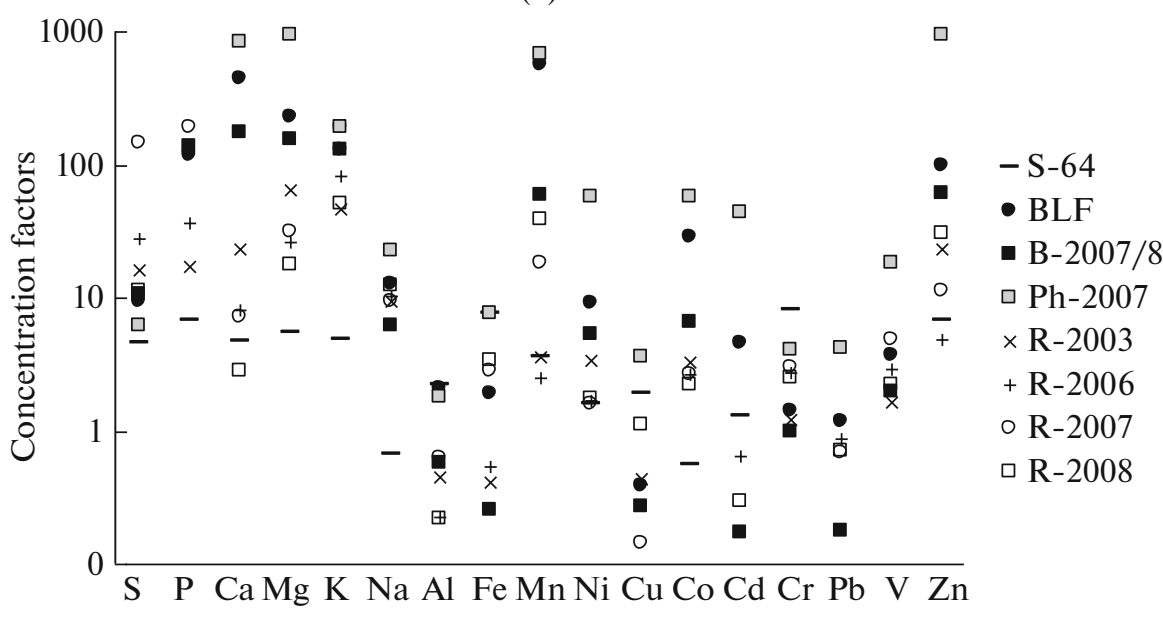

(b)

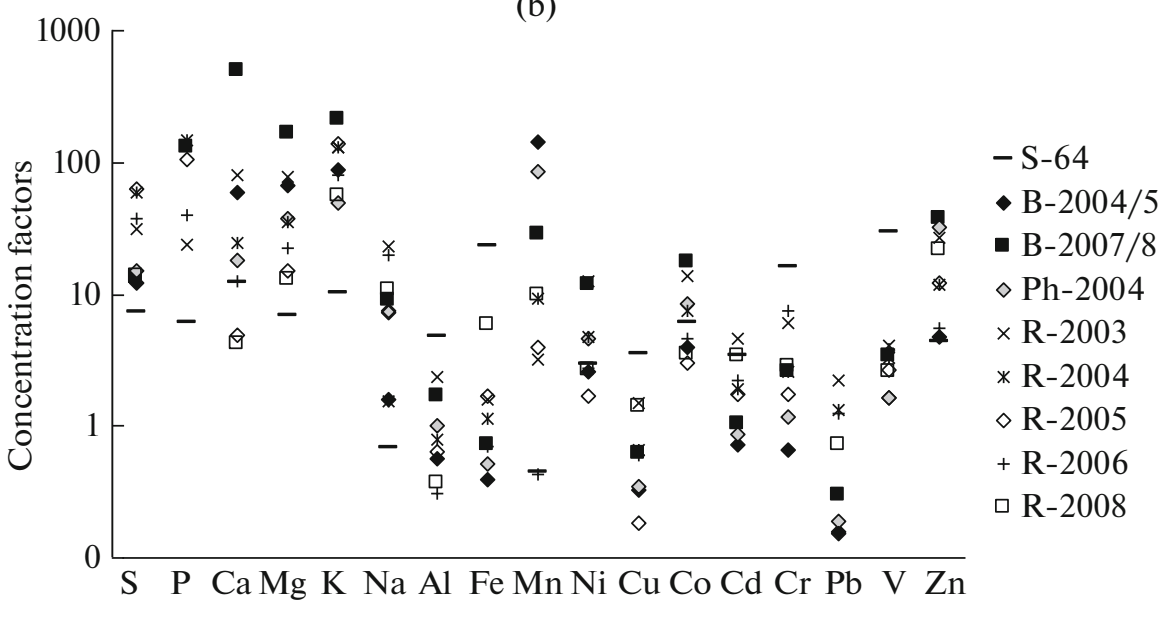

Fig. 4. Concentration factors of elements in the leaves of (a) birch and (b) willow relative to concentrations of available compounds of these elements in soils (logarithmic scale).

The accumulation of elements in leaves of undergrowth relative to the soils of barrens largely reflects the change in soil properties on barren plots, i.e., the depletion of nutrients and the accumulation of heavy metals [9]. The improvement of soil supply with nutrients as a result of remediation measures is accompanied by the closeness of their CF values on remediation plots to the background $\mathrm{CF}$ values. At the same time, the accumulation of HMs in leaves relative to the soils usually remains limited. This fact attests to preservation of the capacity of plants to control their chemical composition owing to protective physiological mechanisms even under severe contamination of technogenic barrens. The capacity of plants to control the input of polluting elements into their leaves was reported in previous studies of the considered region [6-8, 33]. However, this phenomenon is insufficient to ensure successful recovery of plant communities because of unfavorable edaphic conditions. Thinned deciduous young growths dominated by $B$. pubescens and/or $S$. caprea, with greater vitality of the trees, spe- cies diversity, and developed herbaceous cover are formed on barrens only in the case of significant improvement of soil properties as a result of remediation with creation of a new fertile soil layer over the contaminated soil [7, 10].

Hence, judging CF values, both birch and willow are characterized by similar character of the uptake of most elements from soil to their assimilating organs. Low CF values for pollutants confirm the usefulness of choosing $B$. pubescens and $S$. caprea as widely distributed and tolerant to pollution plant species for phytostabilization of polluted soils.

Correlation between elemental composition of plants and soil properties. According to the results of correlation analysis, the uptake of $\mathrm{Ca}, \mathrm{K}, \mathrm{P}, \mathrm{S}$, and $\mathrm{Zn}$ by birch leaves increases with an increase in soil $\mathrm{pH}(r=$ $0.38-0.66, \alpha<0.05$ ). The accumulation of $\mathrm{Ca}$ and $\mathrm{K}$ in leaves reflects soil enrichment with available compounds of these nutrients $(r=0.60, \alpha<0.001$ and $r=$ $0.55, \alpha<0.01)$. Concentrations of polluting metals (Ni, Co, and Zn) in birch leaves weakly correlate with 
their concentrations in the root layer of soils $(r=0.49$, $\alpha<0.01, r=0.45, \alpha<0.05$ and $r=0.59, \alpha<0.001)$. Both willow and birch are characterized by direct correlation between concentrations of $\mathrm{Ca}, \mathrm{K}, \mathrm{P}, \mathrm{S}$ and $\mathrm{Zn}$ in the leaves and soil $\mathrm{pH}(r=0.35-0.48, \alpha<0.05)$. However, among HMs, only $\mathrm{Zn}(r=0.45, \alpha<0.01)$ demonstrates this correlation for willow leaves. The results obtained in our study indicate that the ammonium acetate extraction has a limited capacity to extract HMs available for plants. At the same time, they attest to the capacity of plants and associated microorganisms of the rhizosphere to control the uptake of HMs by roots and their transport to aboveground organs. A narrow range of variation in $\mathrm{HM}$ concentrations within the studied technogenic barrens can also complicate finding of correlative relationships.

Ordination diagrams are in agreement with the results of correlation analysis. The diagrams of properties (Fig. 5) represent plane projections of the first two principal components of indicators of the state of soils under plantations: acidity and the contents of carbon, nitrogen, and available elements (solid arrows). The length of arrows reflects the degree of representation of the properties by the first two principal components, and the cosine of the angle between the arrows approximates the correlation coefficient between the corresponding properties. The external variables (dashed arrows) are described as optimal, in the sense of least squares, expansion coefficients of the corresponding centered property in terms of the principal component basis (and are scaled to the principal component). The approximated properties are equal to the sum of principal components weighted with these coefficients.

Concentrations of $\mathrm{Ca}, \mathrm{K}, \mathrm{P}, \mathrm{S}$, and $\mathrm{Zn}$ in birch and willow leaves increase with an increase in the soil $\mathrm{pH}$. The accumulation of $\mathrm{K}, \mathrm{Ca}$, and, to a lesser extent, $\mathrm{Zn}, \mathrm{Ni}$, and $\mathrm{Co}$ in birch leaves is directly correlated with the contents of their available compounds in soils. Different directions of the vectors indicate a lower degree of these correlations for willow. Under the conditions of reducing atmospheric emissions, this suggests an active regulation of the root uptake of metals and their transport in the acropetal direction by the plants themselves with the help of various protective mechanisms.

Hence, the elemental composition of the plants survived on barren plots and growing in plantations after remediation of the plots near the source of pollution $(2-5 \mathrm{~km})$ reflects complex interactions in the soil-plant system influenced by various factors. Longterm technogenic impact has led to contamination, nutrient depletion, and degradation of soils $[5,7]$. The increase in pollution was accompanied by suppression of plants (disturbance of physiological processes, decrease of productivity, and the appearance of visible symptoms, such as chloroses and necroses, growth rate reduction, and dying of roots), their death, and the formation of technogenic barrens $[5,8,11,13,18]$. The extreme climatic conditions of the Arctic and severe microclimate cause additional stress on plants. Chemophytostabilization appeared to be nonefficient for improving the state of soils and plants under the conditions of intense pollution. The covering of polluted soils with a fertile layer has led to a decrease in the soil acidity and soil enrichment with nutrients and organic matter $[7,9]$ contributing to the formation and development of plant communities [10], in which plant tolerance towards HMs is provided not only by internal metabolic mechanisms but also by such an external factor as the improvement of soil properties. Under the conditions of technogenic pollution, the regulation of $\mathrm{HM}$ uptake by plants is confirmed by the low CF values of metals; it is both metal- and speciesspecific. The distribution of metals in the soil-plant system is characterized by the high spatiotemporal variability and depends on competitive interactions of the metals, atmospheric pollution by continuing emissions, secondary pollution because of dusting of open surfaces, and variable weather conditions.

\section{CONCLUSIONS}

The modern state of plantations created in the course of remediation of technogenic barrens in the Kola Subarctic significantly depends on the continuing industrial pollution, plant tolerance towards pollutants, soil properties, and remediation technology. According to the results of leaf diagnostics, both representatives of deciduous species-B. pubescens and $S$. caprea-demonstrate similar relationships with many elements under the conditions of atmospheric pollution. Both species suffer pronounced misbalance of vitally important elements: shortage of $\mathrm{K}$ and $\mathrm{Ca}$ and deficiency of $\mathrm{P}$ and, especially, $\mathrm{Mn}$ and $\mathrm{Zn}$. The leaves of both species accumulate $\mathrm{Ni}, \mathrm{Cu}, \mathrm{Co}, \mathrm{Cr}, \mathrm{Fe}$, $\mathrm{Al}, \mathrm{S}, \mathrm{Pb}, \mathrm{V}$, and As. However, concentrations of $\mathrm{S}, \mathrm{K}$, $\mathrm{Ca}, \mathrm{Al}, \mathrm{Fe}, \mathrm{Cu}, \mathrm{Ni}, \mathrm{Cr}$, and $\mathrm{As}$ in willow leaves are, on average, 1.5-2 times higher than those in birch leaves. Willow leaves absorb especially high amounts of $\mathrm{Cd}$ and $\mathrm{Co}$, while birch leaves absorb a lot of $\mathrm{Mn}$.

Chemophytostabilization has little influence on the uptake of $\mathrm{Ca}, \mathrm{K}$, and $\mathrm{P}$ by the plants, whereas the creation of a new fertile layer on the surface of polluted soils leads to the enrichment of birch and willow leaves with these biogenic elements, which becomes more pronounced with distance from the industrial enterprise. Accumulation of metals in leaves under the conditions of continuing input from the atmosphere and accumulation of bioavailable heavy metals in soils after remediation [9] is largely determined by the distance from the source of pollution, which attests to the possibility of both root uptake and leaf absorption. The accumulation of $\mathrm{Ni}$ and $\mathrm{Cu}$ in leaves did not decrease in 2018 in comparison with 2011, though there was a tendency towards sulfur depletion in leaves. Judging by the reduced, albeit varying values of the 
(a)

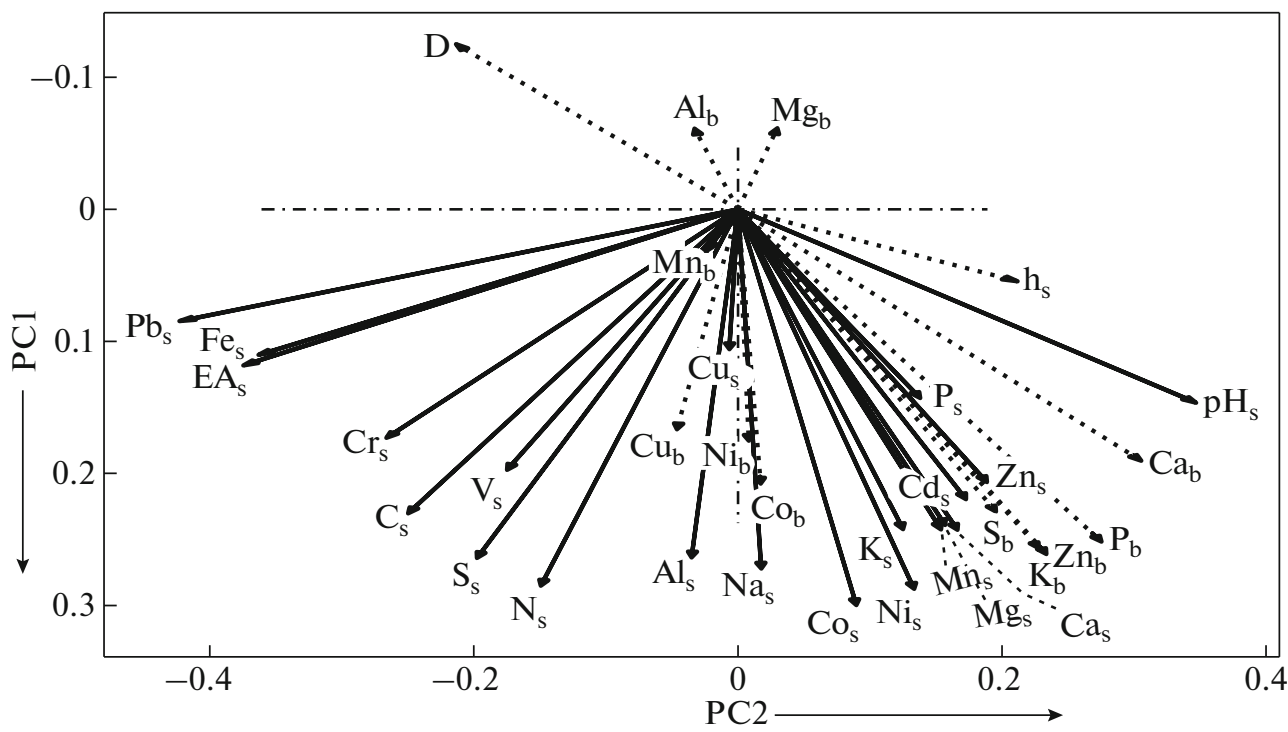

(b)

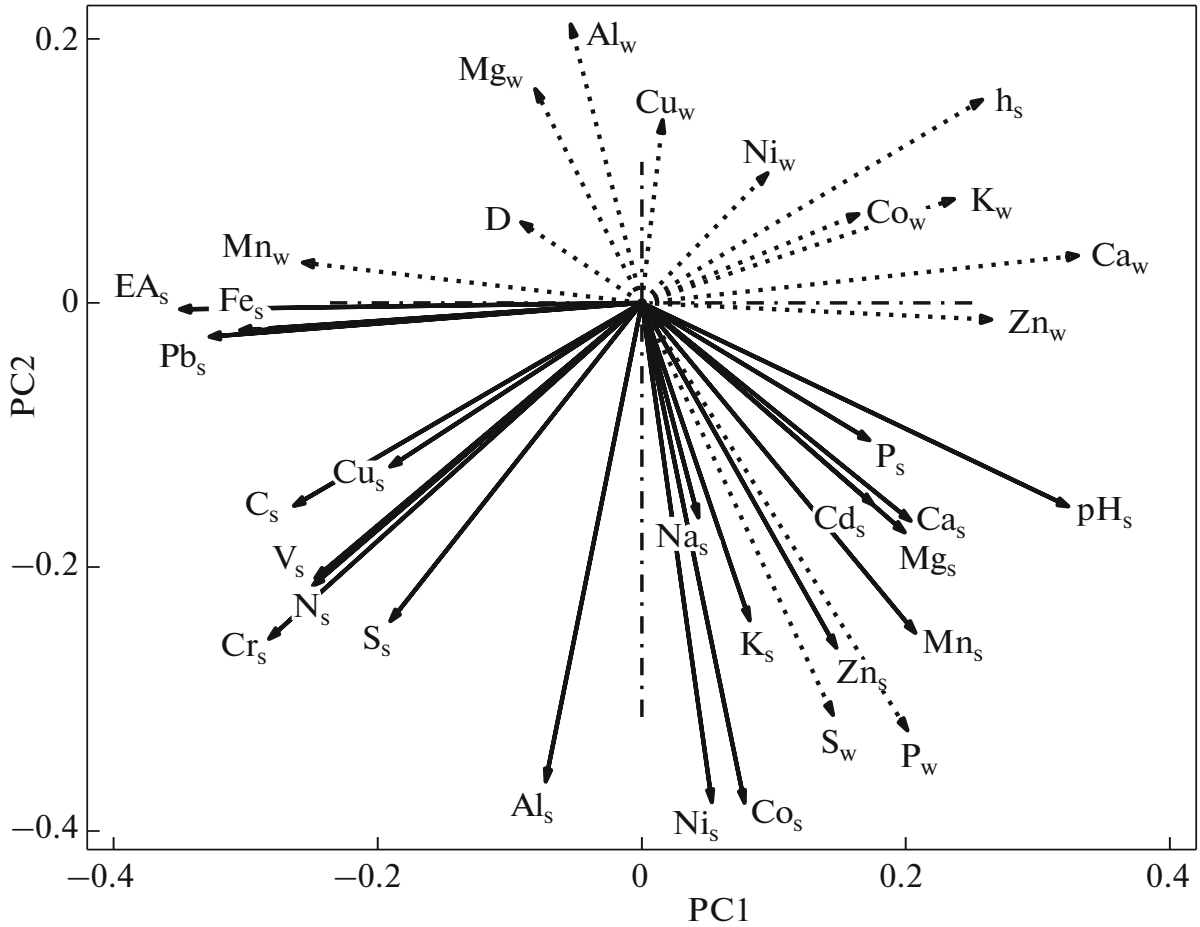

Fig. 5. Ordination diagrams of soil and plant properties in plantations of (a) birch and (b) willow. For ease of comparison of correlation structures, diagram (a) is rotated by $90^{\circ}$, and the directions of the axes are accented with additional arrows [9]. Soil properties are shown with solid arrows; plant properties (as external variables) are shown with dashed lines. Symbols of chemical elements designate concentrations of their available compounds in the upper soil layer (s) and leaves of birch (b) and willow (w); $h$ is the thickness of the upper soil layer enriched in organic matter, and $D$ is the distance from the source of pollution.

concentration factor, both species limit the uptake of potentially toxic $\mathrm{Cu}, \mathrm{Pb}, \mathrm{Al}$, and $\mathrm{Fe}$; birch also limits the supply of $\mathrm{Cd}$ from soils to assimilating organs. According to the results of correlation and multivariate analyses, the concentrations of polluting metals in leaves are weakly correlated with their concentrations in the upper root layer of soils. Apparently, both spe- cies retain the ability to control their chemical composition even under extreme conditions of technogenic barrens. This fact confirms the advisability of choosing $B$. pubescens and $S$. caprea as widespread and tolerant to heavy metals plant species for the remediation of contaminated soils. Simultaneous improvement of soil properties, primarily enrichment with nutrients 
and organic matter and a decrease in soil acidity in combination with a reduction in atmospheric pollution is a prerequisite for the successful remediation of technogenic barrens in the Arctic.

\section{ACKNOWLEDGMENTS}

We are grateful to M.S. Kadulin, Yu.V. Kupriyanova, E.A. Mitireva, and A.D. Volkov (Soil Science Faculty, Lomonosov Moscow State University) for their assistance in field work.

\section{FUNDING}

Experimental study was supported by the Russian Foundation for Basic Research, project no. 18-04-01028. Statistical treatment was performed in agreement with state assignment of the Ministry of Science and Higher Education of the Russian Federation (registration number AAAAA20-120092490029-8).

\section{CONFLICT OF INTEREST}

The authors declare that they have no conflicts of interest.

\section{OPEN ACCESS}

This article is distributed under the terms of the Creative Commons Attribution 4.0 International Public License (http://creativecommons.org/licenses/by/4.0/), which permits unrestricted use, distribution, and reproduction in any medium provided you give appropriate credit to the original author(s) and the source, provide a link to the Creative Commons license, and indicate if changes were made.

\section{REFERENCES}

1. N. I. Bazilevich and A. A. Titlyanova, Biotic Turnover on Five Continents: Nitrogen and Ash Elements in Natural Terrestrial Ecosystems (Siberian Branch, Russian Academy of Sciences, Novosibirsk, 2008) [in Russian].

2. V. E. Zverev, "Mortality and recruitment of mountain birch (Betula pubescens ssp. czerepanovii) in the impact zone of a copper-nickel smelter in the period of significant reduction of emissions: the results of 15-year monitoring,” Russ. J. Ecol. 40, 254-260 (2009).

3. V. B. Il'in, Heavy Metals and Nonmetals in the SoilPlant System (Siberian Branch, Russian Academy of Sciences, Novosibirsk, 2012) [in Russian].

4. A. Kabata-Pendias and H. Pendias, Trace Elements in Soil and Plants (CRC Press, Boca Raton, FL, 1986; Mir, Moscow, 1989).

5. G. M. Kashulina, "Monitoring of soil contamination by heavy metals in the impact zone of copper-nickel smelter on the Kola Peninsula," Eurasian Soil Sci. 51, 467-478 (2018).

6. G. M. Kashulina and N. V. Saltan, Chemical Composition of Plants in the Local Impact Zone of Severonikel Smelter (Kola Scientific Center, Russian Academy of Sciences, Apatity, 2008) [in Russian].
7. G. N. Koptsik, S. V. Koptsik, and I. E. Smirnova, "Alternative technologies for remediation of technogenic barrens in the Kola Subarctic," Eurasian Soil Sci. 49, 1294-1309 (2016).

8. G. N. Koptsik, S. V. Koptsik, I. E. Smirnova, A. D. Kudryavtseva, and K. A. Turbabina, "The response of forest ecosystems to reduction in industrial atmospheric emission in the Kola Subarctic," Zh. Obshch. Biol. 77 (2), 145-163 (2016).

9. G. N. Koptsik, S. V. Koptsik, I. E. Smirnova, and M. A. Sinichkina, "Remediation of technogenic barren soils in the Kola Subarctic: current state and long-term dynamics," Eurasian Soil Sci. 54, 619-630 (2021).

10. V. N. Korotkov, G. N. Koptsik, I. E. Smirnova, and S. V. Koptsik, "Restoration of vegetation on mine lands near Monchegorsk (Murmansk oblast, Russia),” Russ. J. Ecosystem Ecol. 4 (1), 1-18 (2019). https://doi.org/10.21685/2500-0578-2019-1-4

11. Forest Ecosystems and Atmospheric Pollution, Ed. by V. A. Alekseev (Nauka, Leningrad, 1990) [in Russian].

12. I. V. Lyanguzova, "Dynamic trends of heavy metal contents in plants and soil under different industrial air pollution regimes," Russ. J. Ecol. 48, 311-320 (2017).

13. I. V. Lyanguzova, Heavy Metals in Northern Taiga Ecosystems of Russia: Spatio-Temporal Dynamics during Aerial Pollution (LAP LAMBERT Academic, Saarbrucken, 2016) [in Russian].

14. A. V. Nesterkov, "Surface pollution of meadow plants during the period of reduction of atmospheric emissions from a copper smelter," Russ. J. Ecol. 50, 408412 (2019).

15. A. I. Perel'man, Geochemistry (Vysshaya Shkola, Moscow, 1989) [in Russian].

16. I. V. Seregin and A. D. Kozhevnikova, "Roles of root and shoot tissues in transport and accumulation of cadmium, lead, nickel, and strontium," Russ. J. Plant Physiol. 55, 1-22 (2008).

17. V. F. Tsvetkov and E. A. Cherkizov, "Forest reclamation in the impact zone of industrial emissions on the Kola Peninsula," in Impact of Industrial Enterprises on the Environment (Nauka, Moscow, 1987), pp. 112-119.

18. T. V. Chernen'kova, Response of Forest Vegetation to Industrial Pollution (Nauka, Moscow, 2002) [in Russian].

19. A. J. M. Baker, "Accumulators and excluders-strategies in the response of plants to heavy metals," J. Plant Nutr. 3 (1-4), 643-654 (1981). https://doi.org/10.1080/01904168109362867

20. Bio-Geotechnologies for Mine Site Rehabilitation, Ed. by M. N. V. Prasad, (Elsevier, Amsterdam, 2018).

21. R. A. Efroymson, B. E. Sample, and G. W. Suter II, "Uptake of inorganic chemicals from soil by plant leaves: regressions of field data," Environ. Toxicol. Chem. 20 (11), 2561-2571 (2001). https://doi.org/10.1002/etc.5620201123

22. H. Harmens, D. A. Norris, E. Steinnes, E. Kubin, J. Piispanen, R. Alber, Y. Aleksiayenak, et al., "Mosses as biomonitors of atmospheric heavy metal deposition: spatial patterns and temporal trends in Europe," Environ. Pollut. 158, 3144-3156 (2010). https://doi.org/10.1016/j.envpol.2010.06.039

23. M. Intawongse and J. R. Dean, "Uptake of heavy metals by vegetable plants grown on contaminated soil and 
their bioavailability in the human gastrointestinal tract," Food Addit. Contam. 23 (1), 36-48 (2006). https://doi.org/10.1080/02652030500387554

24. J. Kopinga and J. van den Burg, "Using soil and foliar analysis to diagnose the nutritional status of urban trees," J. Arboricult. 21 (1), 17-24 (1995).

25. M. V. Kozlov, E. Haukioja, A. V. Bakhtiarov, and D. N. Stroganov, "Heavy metals in birch leaves around a nickel-copper smelter at Monchegorsk, northwestern Russia,” Environ. Pollut. 90, 291-299 (1995). https://doi.org/10.1016/0269-7491(95)00027-O

26. H. Marschner, Mineral Nutrition of Higher Plants, 2nd ed. (Academic, London, 1995).

27. M. C. Newman, Fundamentals of Ecotoxicology: The Science of Pollution (CRC Press, Boca Raton, FL, 2015).

28. R. Nirola, M. Megharaj, T. Palanisami, R. Aryal, K. Venkateswarlu, and R. Naidu, "Evaluation of metal uptake factors of native trees colonizing an abandoned copper mine-a quest for phytostabilization," J. Sustainable Min. 14 (3), 115-123 (2015).

https://doi.org/10.1016/j.jsm.2015.11.001

29. M. Nordløkken, T. Berg, T. P. Flaten, and E. Steinnes, "Essential and non-essential elements in natural vegetation in southern Norway: contribution from different sources," Sci. Total Environ. 502, 391-399 (2015). https://doi.org/10.1016/j.scitotenv.2014.09.038

30. Phytoremediation of Metal-Contaminated Soils, NATO Science Series 4, Ed. by J.-L. Morel, G. Echevarria, and N. Goncharova (Springer-Verlag, Dordrecht, 2006), pp. 109-190.

31. I. D. Pulford and C. Watson, "Phytoremediation of heavy metal contaminated land by trees-a review," Environ. Int. 29, 529-540 (2003). https://doi.org/10.1016/S0160-4120(02)00152-6

32. C. Reimann, M. Äyräs, V. A. Chekushin, I. V. Bogatyrev, R. Boyd, P. de Caritat, R. Dutter, et al., Environmental Geochemical Atlas of the Central Barents Region (Geological Survey of Norway, Trondheim, 1998).

33. C. Reimann, F. Koller, B. Frengstad, G. Kashulina, H. Niskavaara, and P. Englmaier, "Comparison of the element composition in several plant species and their substrate from a $1,500,000 \mathrm{~km}^{2}$-area in Northern Eu- rope," Sci. Total Environ. 278, 87-112 (2001). https://doi.org/10.1016/S0160-4120(02)00152-6

34. R. Salminen, V. Chekushin, M. Tenhola, I. Bogatyrev, S. P. Glavatskikh, E. Fedotova, V. Gregorauskiene, et al., "Geochemical atlas of Eastern Barents region," J. Geochem. Explor. 83 (1-3) (2004).

https://doi.org/10.1016/j.gexplo.2004.06.001

35. M. Shahid, C. Dumat, S. Khalid, E. Schreck, T. Xiong, and N. K. Niazi, "Foliar heavy metal uptake, toxicity and detoxification in plants: a comparison of foliar and root metal uptake," J. Hazard. Mater. 325, 36-58 (2017). https://doi.org/10.1016/j.jhazmat.2016.11.063

36. A. Tran, K. K. Nkongolo, M. Mehes-Smith, R. Narendrula, G. Spiers and P. Beckett, "Heavy metal analysis in red oak (Quercus rubra) populations from a mining region in northern Ontario (Canada): effect of soil liming and analysis of genetic variation," Am. J. Environ. Sci. 10 (4), 363-373 (2014). https://doi.org/10.3844/ajessp.2014.363.373

37. B. Vandecasteele, E. Meers, P. Vervaeke, B. De Vos, P. Quataert, and F. M.G. Tack, "Growth and trace metal accumulation of two Salix clones on sedimentderived soils with increasing contamination levels," Chemosphere 58, 995-1002 (2005). https://doi.org/10.1016/j.chemosphere.2004.09.062

38. M. Vysloužilová, P. Tlustoš, and J. Száková, "Cadmium and zinc phytoextraction potential of seven clones of Salix spp. planted on heavy metal contaminated soils,” Plant Soil Environ. 49 (12), 542-547 (2003).

39. M. Wahsha, C. Bini, E. Argese, F. Minello, S. Fontana, and $\mathrm{H}$. Wahsheh, "Heavy metals accumulation in willows growing on Spolic Technosols from the abandoned Imperina Valley mine in Italy," J. Geochem. Explor. 123, 19-24 (2012). https://doi.org/10.1016/j.gexplo.2012.07.004

40. Q. Wu, S. Wang, P. Thangavel, Q. Li, H. Zheng, J. Bai, and R. Qiu, "Phytostabilization potential of Jatropha curcas L. in polymetallic acid mine tailings," Int. J. Phytorem. 13 (8), 788-804 (2011). https://doi.org/10.1080/15226514.2010.525562

Translated by T. Chicheva 